\title{
MAKING A LIVING: GRASSROOTS DEVELOPMENT INITIATIVES, NATURAL RESOURCE MANAGEMENT AND INSTITUTIONAL SUPPORT IN GALICIA, SPAIN
}

\author{
María Dolores Domínguez García ${ }^{1}$, Paul Swagemakers ${ }^{2}$, \\ Bettina B. Bock ${ }^{3}$, Xavier Simón Fernández ${ }^{4}$
}

Received 13 May 2011; Accepted 16 December 2011

\begin{abstract}
European policy increasingly supports territorially based rural development in which local actors play a decisive role in realising economically, socially and ecologically responsible development. This paper makes use of four case-studies, from a largely depopulated mountainous area in Galicia, Spain, where local people strive to combine the creation of new businesses with the revitalisation of the natural resource base. The paper, in analysing local knowledge infrastructure and its interface with policy, reveals the dominant role of grassroots development initiatives in effecting regional learning and capacity building. Further it is acknowledged that in Galicia progress is brokered in practice by individual stakeholders who manage structural constraints, cross boundaries and construct new cross-cutting, bridging networks. It is also apparent that these niche-actors constitute a largely untapped reservoir of knowledge brokers that could be used much more effectively if more direct cooperation with policymakers and the existing knowledge infrastructure could be achieved.
\end{abstract}

Keywords: EU support schemes, endogenous knowledge, interface analysis, natural resource management, rural development, rural economy, transition processes

Resumen:Las políticas europeas apoyan cada vez más un desarrollo rural territorial en el que los actores locales juegan un papel decisivo al realizar un desarrollo económico, social y ecológicamente responsable. Este artículo utiliza cuatro estudios de caso localizados en un área con problemas de despoblación en Galicia, España. En los cuatro casos los actores luchan por combinar la creación de nuevas empresas con la revitalización de la base local de recursos naturales. El artículo analiza la infraestructura de conocimiento local y sus interfaces con el ámbito político. De esta forma revela el papel dominante que las iniciativas de desarrollo enraizadas en lo local tienen en la construcción del conocimiento regional y de la capacidad de implementación. En Galicia el progreso se construye a nivel práctico gracias a la

\footnotetext{
1 María Dolores Domínguez García, Departamento de Economía Aplicada, Universidade de Vigo, email: ramstein@uvigo.es

2 Dr. Ir. Paul Swagemakers, Leerstoergroep Rurale Sociologie, Wageningen Universiteit, email: paul.swagemakers@gmail.com

${ }^{3}$ Dr. Ir. Bettina B. Bock, Leerstoergroep Rurale Sociologie, Wageningen Universiteit, email: Bettina.Bock@wur.nl

${ }^{4}$ Dr. Xavier Simón Fernández, Departamento de Economía Aplicada, Universidade de Vigo, email: xsimon@uvigo.es
} 
labor individual de actores que son capaces de manejar limitaciones estructurales, cruzar límites y construir nuevas redes que facilitan sus objetivos. Así, estos actores-nicho constituyen una amplia y no del todo estudiada reserva de conocimiento, que podría utilizarse de forma más efectiva si se lograse una cooperación más directa con los hacedores de política y la infraestructura de conocimiento ya existentes.

Palabras clave: programas de apoyo europeo, conocimiento endógeno, análisis de interfaces, manejo de recursos naturales, desarrollo rural, economía rural, procesos de transición.

\section{Introduction}

In the European Union, policy schemes focused on primary agricultural production are increasingly accompanied and replaced by rural development schemes that aim at stimulating the rural economy in a wider way. Agenda 2000 aimed at creating an integrated and sustainable rural development policy: price policy and market policy (first pillar of the CAP) were to be combined with rural development (second pillar of the CAP). In 2005, a single fund for the second pillar of the CAP was established, the European Agricultural Fund for Rural Development (EAFRD). In 2009, measures were introduced on combating climate change, developing renewable energies, water management, the protection of biodiversity, and the promotion of innovation and accompanying measures for the restructuring of the dairy sector. Council Decision 2006/144/EC set out Community strategic guidelines for rural development for the period $20007-2013^{6}$ with specific attention for the quality of life in rural areas and local capacity building (axis 3 and 4 - LEADER). Although policy focus is increasingly aimed at stimulating the revitalization of rural areas its success has been limited so far (see the report of the United Nation's Special Rapporteur Olivier De Schutter). Many national and regional programmes, often administered by agriculture ministry's/departments or their successors, still focus disproportionately on farm structures and competitiveness (Axis 1) and agri-environment (Axis 2), ignoring the need for supporting rural local economies more widely ${ }^{7}$ and ignoring the potential present in many rural areas, even those that are generally perceived as disadvantaged or marginal and in threat of abandonment. As we will argue in this paper there is an urgent need to explore the economic development potential of a disadvantaged rural region from a broad perspective, in which agriculture may be one of several players. By analyzing the relations and interfaces between Grassroots Development Initiatives (GDIs), the knowledge infrastructure and (rural and agrarian) policies we aim to gain a deeper understanding of the value of endogenous knowledge of niche-actors who combine in the creation of new businesses based on $\mathrm{h}$ the revitalisation of the natural resource base. This analysis of what we see as new and promising rural co-operation is contextualised by the broader challenges of governing sustainable rural development in a globalizing world.

\section{Sustainable development as a socio-ecological process}

In the conventional domains of economics and development studies, limited to its interpretation in monetary terms and money flows, sustainable development is often understood within the optic of self-sustained growth. Sustainable rural development, however, is to be assessed in terms of the availability of physical stocks, the quality of end-products, the generation of labour, and the capacity to maintain and/or improve the quality of the natural environment (Daly 1990, Naredo 1996). This calls for a fundamental re-orientation of the interrelations between society and economy (Haberl et al. 2009). As well as monetary and economic growth, sustainable rural development should therefore include the improvement of ecological capital (van der Ploeg

\footnotetext{
${ }^{5}$ Council Regulation (EC) No 1257/1999 (OJ L 160 of 26.6.1999), http://www.europarl.europa.eu, last accessed $27 / 10 / 2011$

6 Decision 2006/144/EC (OJ L 55, 25.2.2006), as amended by Decision 2009/61/EC (OJ L 30, 31.1.2009), http://www.europarl.europa.eu, last accessed 27/10/2011.

${ }^{7}$ The new multiannual financial framework: http://www.europarl.europa.eu/.
} 
2008, Swagemakers and Wiskerke 2011). Following Rammel et al. (2007:9), we assess sustainable rural development as an 'open evolutionary process of improving the management of social-ecological systems'. An important element in our definition is the systems' capacity to adapt (Holling 2001, Stagl 2007, van der Ploeg 2008) and its ability 'to reconcile the impacts of human activity on the environment' (Murphey 2000:2).

Sustainable rural development (in which natural resource management is incorporated) should allow for processes of change that last in the long-term; it is therefore important that they are territorially rooted (Marsden 2003, Wiskerke 2009) and developed in collaboration with local groups (Bruckmeier and Tovey 2008). From this point of departure, nature and society is to be re-connected from a local actor perspective in which agro-ecosystems (Altieri 1995; 1999,) are perceived as the 'materialized connections' between nature and society (Holloway et al. 2007, Sevilla Guzman and Martínez Alier 2006). The focus should be on the capacities and projects of niche-actors who construct a world in which natural resources are part of that world, and thus of rural development practices and progress based on 'ecological entrepreneurship' (Marsden and Smith 2004). When we conceive rural development as the outcome of knowledge generation in which knowledge is derived from, and maintained by, social interaction (Berger and Luckmann 1966), we allocate an important role to niche-actors in brokering?- economic progress.

In order to make bottom-up initiated innovation successful, complementary top-down measures are required as well (Morgan 1997, Wiskerke 2007). In order to sustain rural development and economic growth, institutional environments are to be developed that encourage private and social learning by individual workers, firms and government bodies (Wellbrock and Roep, 2012). In an environment that is conductive to development it is not only individuals that should learn social learning is also particularly relevant: 'the learning that takes place when divergent oftentimes conflicting- interests, norms, values and constructions of reality meet' (Eernstman and Wals 2007:388).

\section{Interface analysis of regional learning}

In this paper we study regional learning as a social interface: 'a critical point of intersection between different lifeworlds, social fields or levels of social organization, where social discontinuities based upon discrepancies in values, interests, knowledge and power, are most likely to be located' (Long 2001:243). These can take shape in a formalized organisational entity, but often have an informal, often veiled 'appearance' (Long 1999). We develop an actororiented approach (Long 2001) in which actors appear not only as knowledge users but in particular as the producers and disseminators of knowledge and, hence, (potential) knowledge brokers. From our viewpoint, GDIs represent promising practices that may offer 'protected spaces' or 'niches' in which ideas and new behavioural patterns or social configurations can develop (Kemp et al. 1998, Hoogma 2000). In those niches a wide range of actors can learn about limitations and requirements of innovative practices and connect them with existing knowledge and behaviour (Hoogma et al. 2002). The network members learn individually but through their interaction in and outside the group they also contribute to collective learning at a higher, social level and result in successful mainstreaming of niche-innovations (Geels and Schot 2007).

In regional learning, endogenous knowledge has a central position. The practices and progress of the niche-actors may conflict with practices and interests of others. Support by formal knowledge infrastructures and rural policy programmes may, however, facilitate their recognition and effectiveness as knowledge brokers by others, and enable the integration of formal and informal knowledge domains.

In the case-studies below we analyse the interfaces of regional learning in order to better understand the role that GDIs play as knowledge brokers in the transition towards sustainable development, especially in so-called disadvantaged regions. Section 2 outlines the physical and institutional context of the case-study locations and explains the methodologies employed. In section 3 we report on the case-study results; we describe how GDIs success or failure in promoting local development varied according to their interaction with formal knowledge structures and incorporation in policy schemes. Finally, in section 4 , we draw conclusions on 
how these GDIs as niche-actors could contribute more successfully to the further sustainment of rural development in a globalizing world.

\section{Context and methodology}

\section{The case study area}

The Comarca de Verín (map 1: the term 'Comarca' refers to a set of communities that share territorial characteristics) is situated in the high basin of the Támega river, which is surrounded by the mountain systems of San Mamede $(1618 \mathrm{~m})$ and Fial das Corzas in the North; Sierra Seca and Penas Libres $(1083 \mathrm{~m})$ in the East; Sierra de Larouco $(1525 \mathrm{~m})$ in the West, and the Portuguese Valley of Amarante in the South. Many other small rivers cross the area, among them Portos, Trez, Servoi, Gondulfes, Ábedes, Fornos, Baldriz, Soutelilño, Búbal, Queixa, Cabrociños, Hedreira and Mente. About one third of the population in the area $(29,497$ inhabitant, INE 2010a; 2010b) live in Verín, the local town; the other two-thirds live in the municipalities Castrelo do Val, Cualedro, Laza,,Monterrei, Oímbra, Riós and Villardevós and their many small villages (175 habitable areas with many parts totally abandoned). With a surface area of $1,007 \mathrm{~km}^{2}$ the Comarca has a very dispersed population with a density of around 29 inhabitants per $\mathrm{km}^{2}$.

Since the 1960s, when the population was at its highest $(43,285$ inhabitants), many rural citizens migrated to places such as France, Germany and Switzerland. In the last decade, citizens migrated more to the provincial capital, Ourense, resulting in a decrease of over $30 \%$ in the population This demographic decline has been accompanied by a birth rate of $5.2 \%$, a death rate of $15.1 \%$, with the average number of children per woman of 0.9 in 2009 , resulting in an aging population: more than $30 \%$ of current population is over 64 years (IGE 2010, INE various yearsa; INE various yearsb). Scattered over the many villages in the area, the provision of public services to these elderly people is hampered, while in the local town, the Galician average of 50.7 is approached, activity rates (active population/>16 year old population) in the Comarca, represent a static labour market. Influenced by the urban effect of Verín with its strongly developed service sector, the overall activity rate in the Comarca is just over 43. Unemployment rates are twice that of the Spanish average (IGE 2010) and if the municipality of Verín is left out of the equation, $22.9 \%$ of the population in the Comarca is employed in agricultural activities.

The Comarca de Verín has a rich and beautiful natural landscape formed by valleys and mountains. Its sierra is covered to a large extent by the Monte, traditionally a multifunctional mountainous zone covered by trees, bushes and scrub (Soto 2006, Dominguez 2007). Often communally owned and/or managed, over the past decades the Monte increasingly has been abandoned by rural citizens in terms of farm activities. By incorporating the Monte again in daily farm activities, the agronomic productivity and environmental efficiency of agricultural activities can be improved (Simón 1995, Soto 2006, Swagemakers et al. 2012). Characterized by a small-scaled mountain landscape with its rivers and small streams, scattered fields and remote villages, the area is an important reservoir of vineyards, oaks and chestnut trees. Among the traditional activities of inhabitants of the small settlements is the gathering of chestnuts and mushrooms. Further, along with the many vineyards and wine cellars around the municipality of Verín, the re-introduction of autochthonous plant varieties and animal breeds, the biodiversity and landscape diversity increase and the risk of the spread of fires diminishes. 

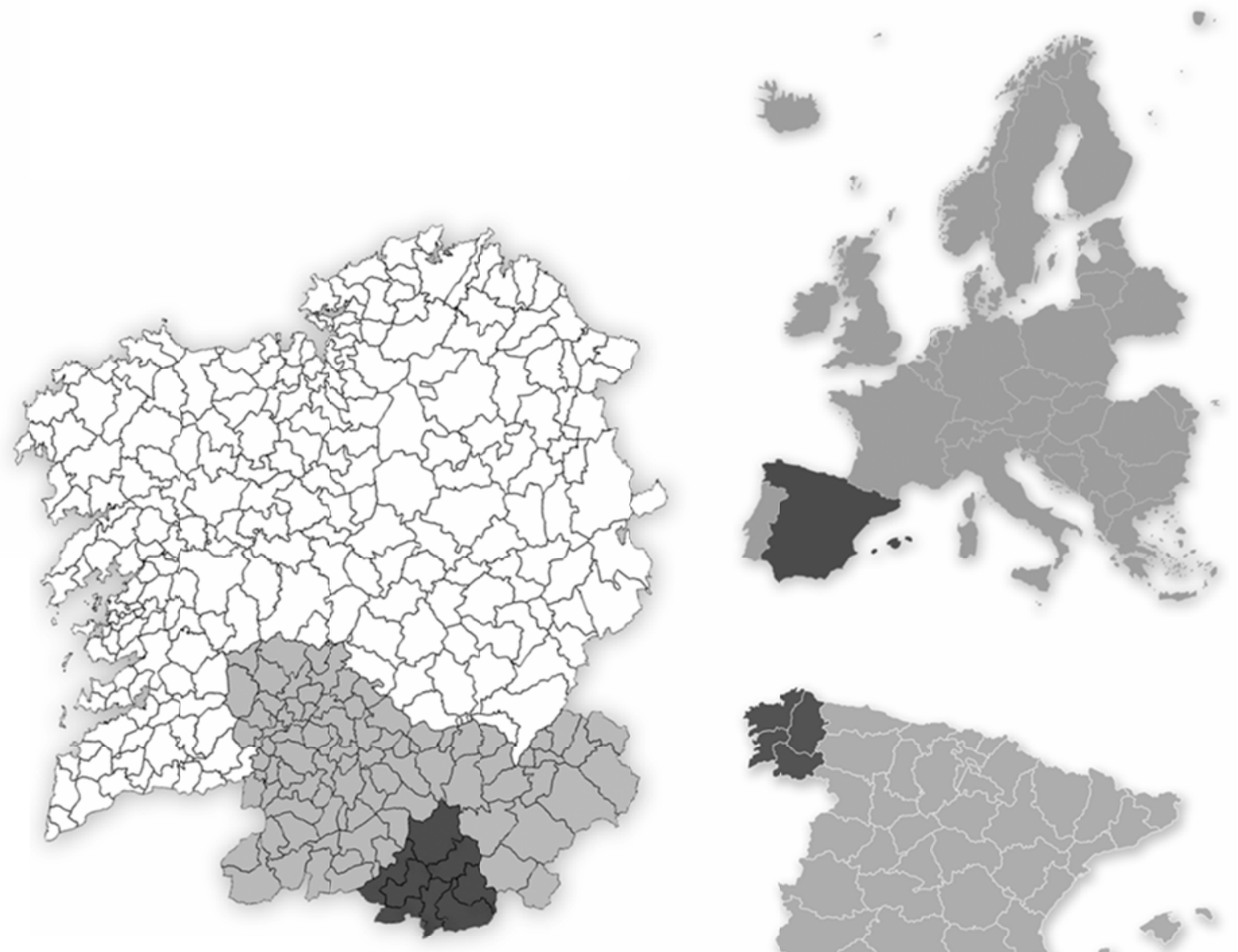

Map 1. Galicia, its four provinces and the Comarca de Verín.

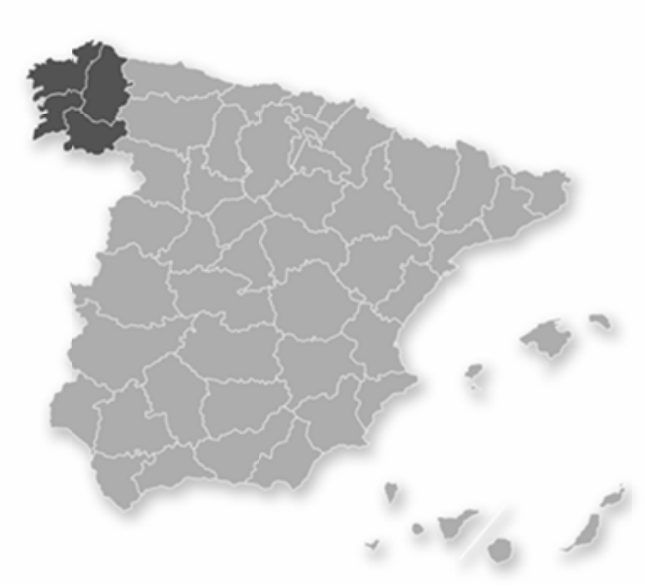

\section{The research methodology}

Case study research (Yin, 1984) attempts to generate understanding and order empirical reality and complexity (Whatmore 1993, Verschuren and Doodewaard 1999). The application of an actor-oriented approach (Long 2001) provides insight into how different aspects, artefacts, people, institutions, and natural resources, interrelate and, in mutual interaction, result in, if carefully balanced, rural development.

In this article we focus on the interface of the three pillars of regional learning and capacity building: grassroots development initiatives, knowledge structures and policies. The relations of these pillars to rural development dynamics were explored in interviews with policy makers and key informants belonging to the local institutional domain: the president and members of NGO Portas Abertas, the secretary of the Local Action Group of the LEADER program, three Mayors, the representative of the OAC (Comarcal Agrarian Office), representatives of FEMURO (Federation of Rural Women from Ourense), O Grelo Verde (a local association promoting organic agriculture) and Biocoop (a farmers' cooperative in Verín). It turned out that the implementation of LEADER programs (Axis 4) had been successfully applied (the budget until 2013 was already completely used) and were mainly related to the support of starting SMEs. This was considered worthy by all interviewees; neverthelless we concluded that the knowledge structure had been weakly developed and the application of the policy schemes lacked orientation on 'greening the rural economy' and/or putting into value the so often abandoned natural resources (Dominguez Garcia et al 2012). Therefore we decided to focus on four GDIs that reflected the characteristics of ecological entrepreneurship: initiatives combining an open-evolutionary process of improving the management of socio-ecological systems and 
the incorporation of producer and consumer relationships. We choose to further analyze Biocoop, A Xuntoira, Quinta da Muradella and O Souto. In semi-structured interviews that lasted about two hours and were recorded using an mp3 IC recorder device, we gathered specific information of which transcripts were made. In some interviews different people joined, increasing the interaction and exchange of opinions about rural development dynamics in the region. In the interviews we (1) obtained general information on the initiative; (2) evaluated support of public administration; (3) evaluated support and facilitation of activities from others (the knowledge infrastructure); (4) obtained prospects of the initiators on how their initiative could develop in the near future. Furthermore, interviewees provided additional information by phone and/or email when we progressed our field research and needed more on the details of the past and/or ongoing network activities.

\section{Ecological entrepreneurship and social organisation in the Comarca de Verín}

The Comarca de Verín is characterized by the lack of appropriate management of the Monte. On the one side, the Monte remains often abandoned and without use, on the other, the social mechanisms that possibly could lead to utilization of the Monte are underdeveloped. Therefore the capacities and projects of niche-actors that express characteristics of ecological entrepreneurship and the socio-ecological systems that reduce these limitations are important to explore. Consequently we analyze how the GDIs relevant technical and social innovations are produced and explore the possible integration of functions and hence performance potential of the distinctive and distinguishable socio-ecological constellation of the Comarca de Verín.

\section{Biocoop}

Over the last 20 years, Jose Luis Vaz experimented with cooperative structures in the research area. In 1998, Jose Luis Vaz converted his conventional dairy farm into an organic beef cattle farm and started Biocoop with the aim of incorporating as many farmers as possible into producing 'more naturally' produced meat (Box 1, Quote 1.1). That same year, Jose Luis started 'his' cooperative together with 11 other farmers. Having convinced more farmers to join and to obtain organic production certificates, Biocoop expanded. Currently, it has around 70 members of which all benefit from the different services the cooperative offers and of which 30 farmers have the right to participate in the decision making processes and the right to vote.

After the foundation of the cooperative, the first challenge was to get conventional farmers involved, the second was to get the meat produced by the (potential) members sold in short food supply chains (Box 1, Quote 1.2). Once successful, this helped convince farmers to join his initiative leading to the present situation whereby Biocoop delivers meat within 48 hours directly to consumers and supermarkets and to specialized butchers, all over Spain. The commercial activities are divided into two systems: in the first, meat is sold as 'client portion in Darfresh system' that includes direct sales of vacuum packed 'fresh' meat to individuals, organic shops, big supermarkets and consumer associations; the second is where meat is sold to butchers and restaurant owners who appreciate the quality of meat derived from autochthonous breeds. In addition the cooperative also offers a wide range of services and products to its members. It provides organic fodder, management advice on organic production methods and requirements, preventive and curative medication and anti-parasite medication, solar and electric fences, seeds and transport of animals to the slaughter house. Furthermore, the technicians of the cooperative provide administrative support for applying for agro-environmental subsidies and fulfilling the Galician organic council regulation (CRAEGA). There is no similar supporting structure in the Comarca de Verín nor in the province of Ourense Further in this case as a niche-actor, Jose Luis had to search for institutional support for organic farming through funding, certification and training as the knowledge on converting a conventional dairy farm into an organic beef farm and the possibilities of selling organic meat required an orientation outside the regular environment of the farmers. Because of this development however, Biocoop now also functions as a 'knowledge broker' in organic farming. 


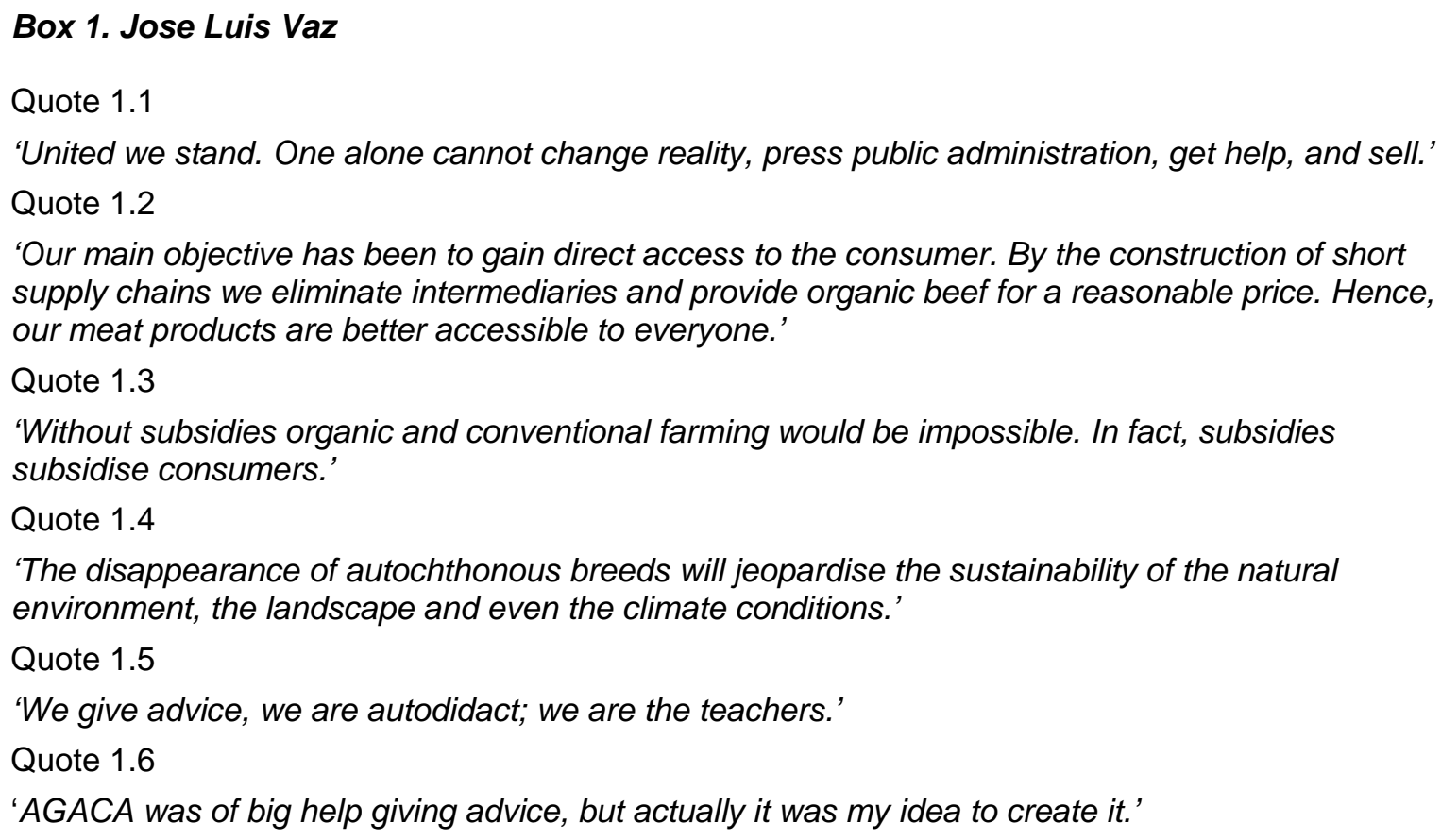

Along with the objective of selling 'naturally produced' meat goes the recovery of endogenous endangered breeds. These adapt best to endogenous environmental conditions and deliver an excellent meat quality on the relatively 'poor' diet they obtain by grazing in the pastures situated higher in the mountains. The adaptation to the natural resource base (Monte) combined with the reduction of the input of concentrates to fatten the calves make autochthonous breeds attractive. The recovery program consists of five breeds: Cachena, Limiá, Caldelá, Frieiresa and Vianesa. The population of these breeds diminished drastically in the last 60 years, and some of them had to be reintroduced in specific technical centres that specialised in breed recovery, and/or taken from other countries such as Portugal. Despite the attractiveness of these breeds in terms of cost reduction and value added if sold in niche markets (restaurant owners appreciate the meat of the Cachena), many coop-farmers continue breeding the Galician rubia, whose larger size (40-50 kilogram heavier than for example the Cachena) once slaughtered, delivers more kilograms of meat compared to the smaller autochthonous breeds. This trade off seems to remain even though these latter breeds are better able to adapt to the mountainous conditions and suffer less from diseases.

In alternative food chains, the quality meat is sold for a price that compensates the 'losses' in production quantity of meat per animal. Subsidies, as they are provided to support conventional farming, are however needed (Box 1, Quote 1.3) to increase the production volume of organic meat and create a supply that can be sold in conventional markets. In 2010, every autochthonous calf slaughtered was compensated by 200 euro of subsidy provided by the Xunta de Galicia (the Galician regional government). An eventual disappearance of the subsidy in 2011 (currently under discussion), jeopardises the evolution of this initiative. While the use of autochthonous breeds fits the organic mode of production, in which the Monte is increasingly used as (part of) the natural resource base, without these subsidies many farmers will choose the more productive breeds; whilst the enthusiasm among beef cattle farmers for using conventional breeds will be strengthened by subsidies. Besides hampering the incorporation of the often abandoned Monte in the productive system, autochthonous breeds, as part of that local resource base, might disappear again, with obvious consequences for landscape and nature (Box 1, Quote 1.4).

As well as the financial aspects of the incorporation of autochthonous breeds into the productive systems, institutional support is important for improving knowledge of organic production methods. As this type of knowledge is lacking at Galician public institutions, Jose Luis and his fellow farmers had to look for their 'own solutions and support' within private, informal networks. 
As the formal knowledge infrastructure, and consequently the technicians providing knowledge to farmers, is oriented toward conventional farming methods, knowledge on organic production was obtained abroad. Consequently, the provision of technical advice to farmers became a task for Biocoop itself. In this way Biocoop has been actively organizing and participating in fairs, symposiums, courses and in collaborations with Vigo University and the University of Santiago de Compostela where knowledge exchange, organising visits for students and participating in conferences have been core elements. Consequently rather than receiving information from the knowledge infrastructure, Biocoop supplies advice and training (Box 1, Quote 1.5) subsequently evolving from a GDI into a mediator in organic production methods. Jose Luis for his part, as illustrated in his involvement in the Galician Association of Cooperatives (AGACA) (Box 1, Quote 1.6) plays a key role as a knowledge broker.

\section{A Xuntoira}

Since the early 1980s, Isaac Barreira has run a wood factory in Berrande (Vilardevós), a village high in the mountains on the border with Portugal. By inviting the villagers to join his initiative, Isaac developed his family enterprise into the cooperative $A$ Xuntoira. Nowadays, with 60 workers and an increased factory floor space from $160 \mathrm{~m}^{2}$ to $7000 \mathrm{~m}^{2}$, the factory produces general carpentry, wooden houses and particularly wooden kitchen doors that are sold all over Europe. Specialisation has increased economic profit and has made $A$ Xuntoira one of the most successful enterprises in the Comarca and a driving force for economic development in the village.

To start the wood factory and develop the initiative, $A$ Xuntoira received institutional support: subsidies for infrastructure, machinery, technology and training. The first support came from LEADER programmes, followed by other European funds that subsidized up-to-the-minute technology. Despite that financial support, Isaac highlighted the lack of economic infrastructure: due to a lack of land mobilisation the Monte as productive area is difficult to access (Box 2, Quote 2.1). Worryingly instead of being produced nearby the factory, the raw materials (woods) are imported from France, Scandinavian countries, Russia, USA and Canada. Issac sees this as a major pitfall (Box 2, Quote 2.2) and a great loss in potential growth for the rural economy (Box 2, Quote 2.3): planting trees, cutting them and using the wood in the factory would give a multiplier effect to the regional economy. In 2010, land consolidation in three nearby parishes was finally approved albeit first the trees have to be planted and grow and as such it will take a long time before this will result in economic benefits directly coming to the villagers.

\section{Box 2. Isaac Barreira}

\section{Quote 2.1}

'Ten years ago we formed a sub-comarca, 'O salto do cabalo', referring to a mountain in the area. We asked for land consolidation in nine villages. We only got three involved: Berrande Soutochao and A Trabe. We were especially interested in chestnut trees. Everything that is covered by bushes, we could use to plant chestnut trees.'

Quote 2.2

'If you do but your neighbour does not and the fire comes, the fire destroys everything.'

Quote 2.3

'All our raw material comes from abroad (...). We speak about millions of euro that we could have produced in the area over the past 20 years. We have plenty of communal Monte that is abandoned.'

Quote 2.4

'In our village, $90 \%$ of the population is retired. Fixing population demands infrastructure and land consolidation.'

The slow speed of policy-making and implementation limits successful regional development. Although the cooperative has initiated land consolidation, it has not yet profited from this 
initiative. Isaac is concerned about the abandonment of the productive part of the Monte, which is mostly under common property. In this respect there is needed an appropriate land consolidation policy or a good land planning strategy that will enable the use of abandoned land for wood production. As any good rural development plan is integrated across and between domains, according to Isaac, the lack of jobs and social services make it difficult to keep he village populated (Box 2, Quote 2.4) which in turn makes it difficult to find 'trained' people. In completeing the cycle where there are trained people, due to eth lack of services, these often leave the area.

Further, an argument raised by Issac was that funds as well as activities that are funded remain poorly managed. In Isaac's opinion, instead of investing in activities that might not last, European funds should be oriented towards entrepreneurial activities that create a strong economic sector. At the moment, people who receive funds lack entrepreneurial training and vision, even though training facilities are available. Portas Abertas for example, the nongovernmental mediating organisation, provides ideas and technical support related to rural development and has been successful in implementing the first LEADER program, yet currently remains without funds.

A Xuntoira has been created by a niche-actor, Isaac, the director of the cooperative since the beginning, who acts as a knowledge broker. Over the years, his initiative has flourished thanks to personal effort and, in the beginning, support of the European Union and associated local mediators. Isaac observes how differences in interests and local struggles put the once important mediators aside. The relevance and need for a knowledge infrastructure and policies supporting sustainable rural development, like institutes that develop policy on the mobilisation of land (productive grasslands, forests as well as Monte) is recognized, but evolves slowly. Rural development programmes support entrepreneurship and development of rural business but hardly consider long-term consequences of the activities they promote.

\section{Quinta da Muradella}

By the end of the 1980s, Jose Luis Mateo decided to become a wine producer. Convinced of the potential of the Comarca, he started his small wine cellar Quinta da Muradella in 1991. His goal was to produce not only distinctive wines by recovering and using local varieties but also to have a significant socio-economic and environmental relevance. The study of the history of wine production in the Comarca would contribute to the recovery of the endangered local varieties and endogenous knowledge on the maintenance of old vineyards and the production of grapes. By carrying out field research (Box 3, Quote 3.1) and following training as a winemaker, over the years he increased the quality of his wines. Nowadays, his best internationally recognized wines result from the recovery of old ancient vine stocks. Whilst recovering many of the old vineyards, which he elaborates with traditional techniques based on endogenous knowledge (Box 3, Quote 3.2) of elderly villagers, he developed into a remarkable wine producer: the vineyards in which he grows the grapes from which he produces his most exclusive wines are located in otherwise abandoned parts of the Monte. Quinta da Muradella is located in the municipality of Verín and, depending on the burden of (seasonal) work, has a range between one and five workers.

\section{Box 3. Jose Luis Mateo}

Quote 3.1

'I am lucky because I learn from old people who taught me without giving lesson.'

Quote 3.2

'What these people do is pure ecology: they maintain the balance of the soil.'

Quote 3.3

'The exclusivity is in the variety. By neglecting this aspect and focusing on the area, the POD contributes to the loss of tradition. For example, the varieties I use, like Zamarrita, Verdello Tinto, Monstruosa de monterrei, Torrentes, are not included within the POD.' 
As villagers were ageing and no longer able to maintain their vineyards, these were close to destruction. Jose Luis recovered them and learned from the villagers how to improve their productivity. Besides the knowledge provided by the villagers, Jose Luis received support and information from local, national and European public organisations and funding bodies: from the Oficinas Agrarias Comarcales (OAC, the Agrarian Extensive Services), the European Fund for Regional Development (ERDF), LEADER II and INTERREG programs. He followed a master course organised by private wine cellars outside Galicia on wine elaboration and attended courses at the University of Vigo. While in the Comarca, the Protected Origin Designation (POD) of Monterrei (after the castle in the Comarca) plays an important role in re-structuring the sector, its activity did not benefit this initiative. In fact Jose Luis thinks the implemented regulations miss and possibly even are counterproductive to the opportunities he sees for the production and marketing of distinctive and good wines in the Comarca (Box 3, Quote 3.3).

Although Jose Luis and the wine production of Quinta da Muradella embodies a great potential for regional learning and capacity building, the philosophy and entrepreneurial strategy that have brought this success has not been followed up. Jose Luis remains a niche-actor; and despite his successful business strategy and the sustainment of the natural resource base, within the current institutional setting his role as knowledge broker is limited.

\section{O Souto}

In the early 1980s, the idea to start a chestnut tree association was born (Box 4 Quote 4.1) but it would take another 20 years until Jose Luis Pérez initiated $O$ Souto, a civil association in Vilardevós where he was Mayor. Together with Paco, a technician working for the municipality, he tried to organize chestnut tree owners into this formal association (Box 4, Quote 4.2). Their aims were to improve the 'profit' of chestnut gathering (a local traditional activity) for the villagers, to improve and increase Soutos (Galician for chestnut tree fields) and to create a population of trees and varieties in the municipality.

In the Comarca, like in other parts of Galicia, a tree is individually owned and can be located in a field that belongs to someone else. Hence, organizing participation is difficult. In 2010, around $60 \%$ of the owners and around 40,000 trees from a total of 100,000 were members. Further growth of the initiative was constrained by a lack of a cooperative mentality. Besides having to pay a contribution, people often were against changes that could possibly affect their properties: as the proposal for land consolidation was related to the initiators of $O$ Souto, many people distrusted the objectives of the association.

Although membership is open to villagers in other municipalities, these groups were even harder to convince and an attempt to create a macro-association together with municipalities in the neighbouring Comarca de Viana failed because of political pressure and local power clashes.

\section{Box 4. Jose Luis Pérez}

Quote 4.1

'The chestnut tree faces problems. There was not any chestnut tree census of the plantations, neither a study of the (chestnut) varieties.

Quote 4.2

"Our task is essentially to show chestnut tree owners the benefits of organizing plantations as the one we have here [shows a field], a Souto that is 15-20 years old and with varieties such as the Famosa and the Longal that are the most valued by the market.'

Quote 4.3

'The unutilized potential has not been considered important by the regional administration.'

Since 2001, the association has called for land consolidation in the area. In 2007 a plan for land consolidation in eight villages (three parishes) was approved. As it took almost seven years to 
get the proposal accepted, it will take years again to implement and benefit from it. Recently, the Geographical Protected Designation of the Galician chestnut has been approved. Although all these years institutional support remained limited (Box4, Quote 4.3), local public support has been guaranteed: the costs of announcements, the provision of meeting rooms and looking for funds for the administrative part of the association were taken care of and/or coordinated by Jose Luis in his role as Mayor.

Chestnut trees have an important economic impact on livelihoods in the area: in some cases, gathering and selling of chestnuts provide over half of the yearly monetary income in a period of a few months. This is of huge importance for the success of the association brokered by the niche-actors allied to the initiators pointing also to the fact that chestnut plantations generate and improve the biodiversity, conserve the landscape structure, avoid fires and result in $\mathrm{CO} 2$ sequestration.

\section{Performance potentials and the constitution of a new rural constellation}

The GDIs embody endogenous knowledge on natural resource management and social organisation and 'materialize' the capacity of niche-actors to build something new, based on local natural resources. By putting formerly abandoned natural resources to new use, they revitalised locally present traditional resources - the material natural resources (soil, trees, breeds, etc. - ecological capital) and also traditional knowledge and experience (human capital) and with it the relevant social relations (the social capital). By embedding these initiatives in a network of internal and external relations, they managed to realize technical and social innovations and foster long-term sustainable rural development. Since European funding schemes became politicized, these socio-ecological elements of a new rural constellation remain rather isolated, each active in and for their own network. The further development and mainstreaming of the initiatives is hampered by a lack of sufficient formal support, leaving it up to individual actors to realise successful initiatives 'from the grassroots'. Combining the initiatives in a rural development plan would, at least on paper, induce rural economic growth and, as all the initiatives make use of the local natural resources in a sustainable way, economic growth could be realised without losing or diminishing the natural resource base.

The chestnut production in the region (recently the destination of origin is approved), picked by the villagers and transported to a central point, either by the producers or locals gathering the chestnuts among the villagers in the region, is to a large extent sold outside the region. From here they are sold all over Galicia (fresh consumption) and to France (industrial processing). Planting (chestnut) trees in otherwise abandoned mountainous areas (improving the natural resource base) would benefit both the land owners (gaining profit) and the wood factory (gaining access to the potentials of the local natural resource base while reducing costs). The creation of an association of tree owners combined with the wood being processed inside and the manufactured products being sold outside the region would benefit all and would very likely improve the regional economy. This would increase by the introduction of beef cattle (or like in other areas: goats) that is adapted to the poorer fields higher up in the mountains and the recovery and reconstruction of vineyards in the area. Both meat and wine can be locally processed and again be sold outside the area.

Although seeds of transition are being developed and sustained in niche-markets by nicheactors, in order to broaden the scope of local economic activities different forms of support and facilitation to set up new projects and activities are required. The incorporating of others in the dynamics we have mapped would further enlarge the scale and with that the impact of this type of activities. In the Comarca de Verín, the public administration supports the start of new initiatives by providing advice and information on funding schemes and facilitates the application to these schemes and the financing of new initiatives. Although the niche-actors do not defend a permanent flow of financial support, they perceive the current way of public administration of understanding development processes as insufficient and counterproductive. The public administration communicate their requirements to give out subsidies in a clear and efficient way but lack a constructive normative frame on what type of rural development should be achieved in the area. There is still an important disconnect between the appropriate application of policy schemes, the knowledge infrastructure and endogenous rural development potentials and 
opportunities. In our opinion, a new organizational structure with more cooperative management, should reflect and further develop the institutions, and ensure the collective and objective patterns of acting, thinking and feeling, which exert a stimulating and controlling influence on individual and subjective actions, thoughts and feelings' (Zijderveld 2000:32), and ultimately that which can coordinate social action in the research area and 'mediate' the application of external rules and the necessary changes in these rules and regulations through which individuals 'achieve their own long-term self-interest' (Ostrom 2000:137).

\section{Conclusions}

Case study research in a remote rural area in Galicia, Spain, provided a context for analyzing how interfaces between rural development initiatives, knowledge infrastructure and policies do, and can effect regional learning and capacity building. Regarding the 'greening' of the rural economy, we conclude that in Galicia progress is brokered in practice by individual stakeholders who manage structural constraints, cross boundaries and construct new boundary crossing networks. These niche-actors constitute a largely untapped reservoir of knowledge brokers that could act in network activities that respond to future policy calls on sustainable rural development: combining economic growth of the rural economy with the preservation and improvement of (scarce) natural resources.

As we learn from our case study research, niche-actors such as the GDIs explored here, successfully contribute to sustainable rural development by creating linkages with the 'outside world', accessing local knowledge and by acting as knowledge brokers. The potential impact of their contribution to sustainable development in the Comarca de Verín however remains limited, due to the lack of alliances with and support of the formal knowledge infrastructure. As long as the identified local niche-actors act on their own as singular knowledge brokers and are not embedded in a learning network in which the formal knowledge infrastructure also participate, their potential remain underused. Examining the role of individual private actors as knowledge users as well as producers and disseminators of knowledge, we conclude that informal regional learning should be supported by an adequate policy framework. However, as institutional support depends on politics, local figures holding power limit the capacity of others to act. Patron-client relationships further hamper the unfolding of the relevant actor-networks and hamper access to required markets. Hence, ecological entrepreneurship and the further 'greening' of rural economic growth remain limited as well.

The initiators of the GDIs have a clear and similar objective: making a living out of agricultural activities that respect and improve the scarce and often abandoned natural resources in the case study area. Rural-urban relationships created by the initiators sustain their businesses; but as intervention of EU policies is not adequately implemented by local power-holders, GDIs are not recognised as relevant partners and not included in formal development alliances. Consequently GDIs remain isolated and confined to their particular local niche, each with its own relations to the outside world, but without weaving a web of mutual collaboration and social learning. As a result endogenous knowledge of, and engagement in, sustainable rural development remain largely underemployed.

References

[1] Altieri, M. A. (1999). Agroecología: Bases científicas para una agricultura sustentable. Montevideo: Nordan-Comunidada.

[2] Altieri, M. A. (1995). Agroecology: The Science of Sustainable Agriculture, $2^{\text {nd }}$ ed. Boulder: Westview Press.

[3] Berger, P. \& Luckmann, T. (1966). The social construction of reality. A treatise in the sociology of knowledge. London: The Penguin Press.

[4] Bouhier A. (1979). La Galice. Essay geographique d'annalyse et d'interpretation d'un vieux complex agraire. La Roche-sur-Yon: Imprimerie Yonnaise. 
[5] Bruckmeier, K. \& Tovey, H. (2008). Knowledge in sustainable rural development. From forms of knowledge to knowledge process. Sociologia Ruralis 48(3), 313-329. Doi: 10.1111/j.1467-9523.2008.00466.x.

[6] Daly, H. E. (1990). Toward some operational principles of sustainable development. Ecological economics 2(1), 1-6. Doi: 10.1016/0921-8009(90)90010-R.

[7] Dominguez Garcia, M. D. (2007). The way you do, it matters. PhD Thesis. Wageningen: Wageningen University.

[8] Domínguez García, M. D., Swagemakers, P., Simón Fernández, X. \& Wiskerke J. S. C. (forthcoming). Constituting connections and rural revitalization in 'the Comarca de Verín', Galicia (Spain). In McDonagh, J. Nienaber, B. \& Woods, M. (eds) Globalization and Europe's Rural Regions. Aldershot: Ashgate.

[9] Eernstman, N. \& Wals, A. E. J. (2009). Interfacing knowledge systems. Introducing certified organic agriculture in a tribal society. NJAS 56(4), 375-390. Doi: 10.1016/S15735214(09)80005-5.

[10] Geels, F. W. \& Schot, J. (2007). Typology of sociotechnical transition pathways. Research policy 36(3), 399-417. Doi: 10.1016/j.respol.2007.01.003.

[11] Haberl, H., Fischer-Kowalski, M., Krausmann, F., Martinez-Alier, J. \& Winiwarter, V. (2011). A socio-metabolic transition towards sustainability? Challenges for another Great Transformation. Sustainable development 19(1), 1-14. Doi: 10.1002/sd.410.

[12] Holling, C. S. (2001). Understanding the complexity of economic, ecological, and social systems. Ecosystems 4(5), 390-405. Doi: 10.1007/s10021-001-0101-5.

[13] Holloway, L., Kneafsey, M., Venn, L., Cox, R., Dowler E. \& Tuomainen H. (2007). Possible food economies: A methodological framework for exploring food production-consumption relationships. Sociologia Ruralis 47(1), 1-19. Doi: 10.1111/j.1467-9523.2007.00427.x.

[14] Hoogma, R. (2000). Exploiting technological niches. Strategies for experimental introduction of electric vehicles. PhD. thesis. Enschede: Twente University Press.

[15] Hoogma R., Kemp, R., Schot, J. \& Truffer, B. (2002). Experimenting for sustainable transport. The approach of strategic niche management. London/New York: Spon Press.

[16] IGE 2010. Fichas comarcais. Instituto Galego de Estatística: www.ige.eu (Last accessed 05/10/2011).

[17] INE Various years a. Padrón Municipal. Instituto Nacional de Estadística: www.ine.es (Last accessed 04/10/2011).

[18] INE Various years b. Movimiento natural de la poboación. Instituto Nacional de Estadística: www.ine.es (Last accessed 05/10/2011).

[19] Kemp, R., Schot, J. \& Hoogma, R. (1998). Regime shifts through processes of niche formation. The approach of strategic niche management. Technology Analysis and Strategic Management 10(2), 175-196. Doi: 10.1080/09537329808524310.

[20] Long, N. (2001). Development sociology. Actor perspectives. London: Routledge.

[21] Long, N. (1999). The multiple optic of interface analysis. UNESCO background paper on Interface Analysis.

[22] Marsden, T. (2003). The condition of rural sustainability. Assen: Van Gorcum.

[23] Marsden, T. \& Smith, E. (2005). Ecological entrepreneurship. Sustainable development in local communities through quality food production and local branding. Geoforum 36(4), 440-451. Doi: 10.1016/j.geoforum.2004.07.008.

[24] Morgan, K. (1997). The learning region: institutions, innovation and regional renewal. Regional Studies 31(5), 491-503. Doi: 10.1080/00343409750132289. 
[25] Murphey, J. 2000. Ecological Modernisation. Geoforum 31(1), 1-8. Doi: 10.1016/S00167185(99)00039-1.

[26] Naredo, J. M. (1996). Sobre el origen, el uso y contenido del término 'sostenible'. Documentación Social 102, 129-147.

[27] Ostrom, E. (2000). Collective Action and the Evolution of Social Norms. The Journal of Economic Perspectives 14(3), 137-158. Doi: 10.1257/jep.14.3.137.

[28] Ploeg, J. D. van der (2008). The new peasantries. Struggles for autonomy and sustainability in an era of empire and globalisation. London: Earth Scan.

[29] Ploeg, J. D. van der (2003). The virtual farmer. Assen: Van Gorcum.

[30] Rammel, C., Stagl, S. \& Wilfing, H. (2007). Managing complex adaptive systems - A coevolutionary perspective on natural resource management. Ecological economics 63(1), 921. Doi: 10.1016/j.ecolecon.2006.12.014.

[31] Sevilla Guzmán, E. \& Martínez Alier, J. (2006). New rural social movements and agroecology. In Cloke, P., Marsden, T. \& Mooney, P. H. (eds), Handbook of Rural Studies (pp. 472-483). London: Sage.

[32] Simón Fernández, X., (1995). Economía ecológica, agroecología y desarrollo rural sostenible. Agricultura y Sociedad 77, 199-236.

[33] Soto, D. (2006). Historia dunha Agricultura Sustentábel. Transformacións productivas na agricultura galega contemporánea. Xunta de Galicia, Consellería de Medio Rural. Colección EIDOS, n. 4.

[34] Stagl, S. (2007). Theoretical foundations of learning processes for sustainable development. International Journal of Sustainable Development \& World Ecology 14(1), 52-62. Doi: 10.1080/13504500709469707.

[35] Swagemakers, P. \& Wiskerke J. S. C. (2011). Revitalizing ecological capital. Geografisk Tidsskrift - Danish Journal of Geography 111(2), 149-167.

[36] Swagemakers, P., Domínguez García, M. D., Simón Fernández, X., \& Wiskerke, J. S. C. (2012) forthcoming. Unfolding farm practices: Working towards sustainable food production in the Netherlands and Spain. Journal of Agriculture, Food Systems and Community Development.

[37] United Nations (2010). A/HRC/16/49. Annual report submitted to the Human Rights Council by the Special Rapporteur on the right to food, Olivier De Schutter.

[38] Verschuren, P. \& Doodewaard, H. (1999). Designing a research project. Utrecht: Lemma.

[39] Wellbrock, W., Roep, D., Wiskerke J. S. C. (2012). An integrated perspective on rural regional learning. European Countryside 4(1), 299-314. DOI: 10.2478/v10091-012-0010-y.

[40] Whatmore, S. (1994). Farm household strategies and styles of farming. Assessing the utility of farm typologies. In van der Ploeg, J. D. \& Long, E., (eds), Born from within. Practices and perspectives of endogenous rural development (pp. 31-37). Assen: Van Gorcum.

[41] Wiskerke, J. S. C. (2009). On places lost and places regained: Reflections on the alternative food geography and sustainable regional development. International Planning Studies 14(4), 369-387. Doi: 10.1080/13563471003642803.

[42] Wiskerke, J. S. C. (2007). Robust regions: Dynamics, coherence and diversity in the metropolitan landscape. Inaugural lecture. Wageningen University.

[43] Yin, R. K. (1984). Case study research: design and methods. London: Sage.

[44] Zijderveld, A. C. (2000). The institutional imperative: the interface of institutions and networks. Amsterdam: Amsterdam University Press. 